\title{
EVALUATION OF POSTGRADUATES STRICTO SENSU: MONITORING POLICY FOR INTERNATIONAL GRADUATES
}

Avaliação de egressos da pós-graduação estrito senso: política de monitoramento de egressos internacionais

Wilma Terezinha Anselmo Lima

A B STRACT

Objective: Search for references in relationship to international alumni on the website of the postgraduate programs of all postgraduate courses at Ribeirão Preto Medical School - FMRP. Methods: Verify with more attention to the ones with 5, 6 and 7 notes, and also the same search on the website of courses with notes 5, 6 and 7 of CAPES - Medicine III. Results: Of the 22 programs of FMRP only three had any information on the site about the destiny of the postgraduates; they were: Surgical Clinics, Genetics, and Basic and Applied Immunology. Programs in the area of Medicine III, notes 5, 6 and 7, only Ophthalmology and Visual Programs and Translational Sciences Surgery, both of UNIFESP, presented such information. Conclusion: It is urgent: to create project and funding evaluation mechanisms that are approved by different sources; to stimulate more efficient controls in relation to teachers and their students who participate in these projects; and to stimulate the interaction of teachers and students with the institution and the program.

Key Words: Evaluation of graduates. Monitoring policy. International postgraduates.

\section{INTRODUCTION}

Ithough in recent years intense discussion about the importance of this issue has begun, very little was actually done to assess the real effective, clear and objective evaluation of alumni of postgraduate courses in our country. Assessment of international postgraduates is even much more difficult. However it is imperative to start, somehow, to establish strategies if we really want to have our courses fully internationalized.

Thus, this article aims to verify specific data on the programs website about the destiny of the international postgraduates.

\section{METHOD}

Trying to reflect on how and where to start to know what has been done by the current CAPES postgraduate courses, active surveillance was conducted initially on the websites of all postgraduate courses at FMRP-USP. Was tried to pay more attention to courses with notes 5, 6 and 7 . Then the same search was conducted in the websites of courses only with notes 5, 6 and 7 disposable on Medicine III - CAPES evaluation processes.

\section{RESULTS}

Demand in all sites of the FMRP-USP courses met harsh reality: from the 22 programs recommended by CAPES, only three made reference to some data on postgraduates destiny. They were: Surgical Clinic, Genetics, and Basic and Applied Immunology. In relation to all programs with notes 5, 6 and 7 in Medicine III, only Ophthalmology and Visual Sciences courses and Translational Surgery, both from the Federal University of São Paulo - UNIFESP, had data about alumni.

Normally, the reference was to historical data, postgraduates names and their respective advisors, start and end date of graduation, composition of exam board, practice area, current activity, regional, national and international maps. It can be cited, as an example, the Basic and Applied Immunology FMRP-USP as the better and more complete (Figures 1, 2, 3 and 4).

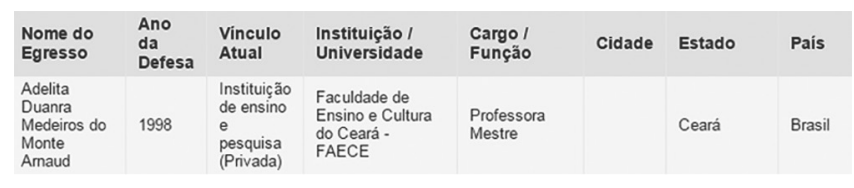

FIGURE 1 - Alumni list

\section{Lista de Alunos Egressos}

Pesquise por qualquer um dos filtros abaixo:

Resultado: 266 itens

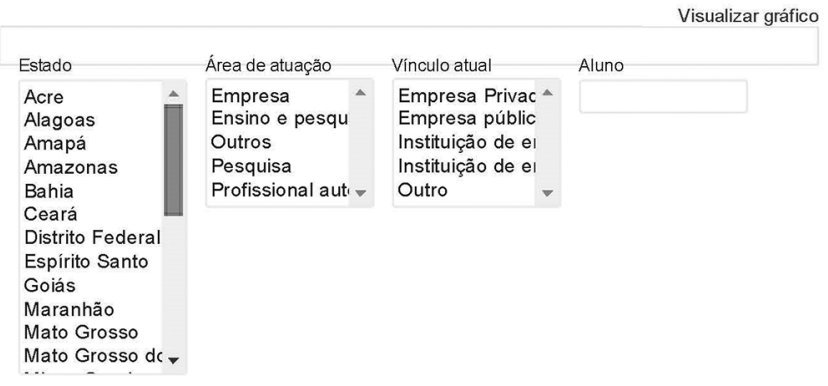

FIGURE 2 - List of alumni with areas and current activity

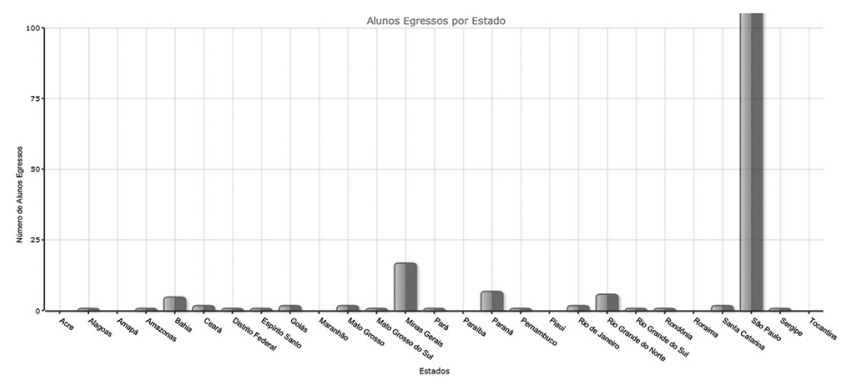

FIGURE 3 - Alumni state prevalence in Brazil

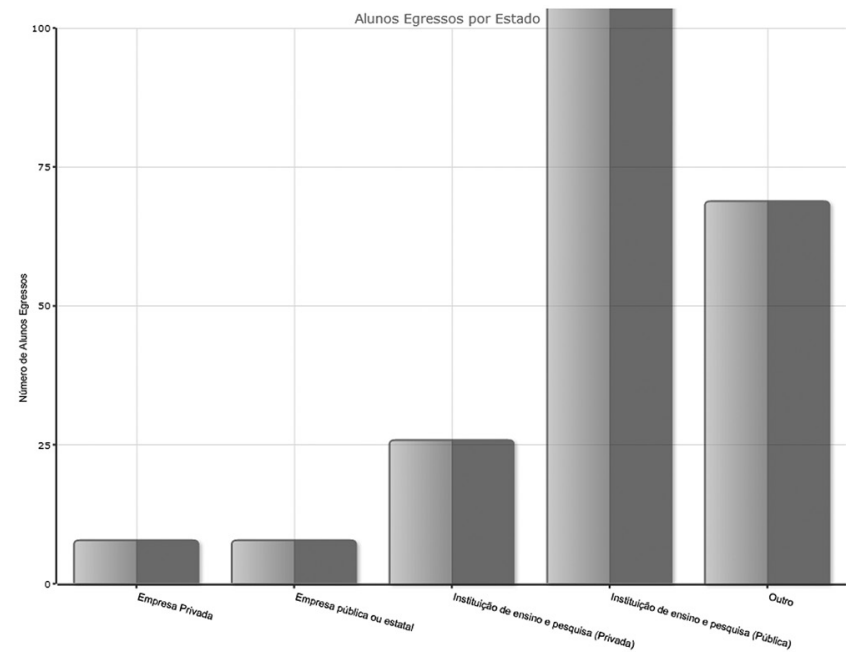

From the Disciplina de Otorrinolaringologia, Faculdade de Medicina de Ribeirão Preto - FMRP, Universidade de São Paulo (Department of Otolaryngology, Faculty of Medicine of Ribeirão Preto - FMRP, University of São Paulo), Ribeirão Preto, SP, Brazil 


\section{FIGURE 4 - Alumni with their current activities}

Interesting is the map shown in Figure 5, taken from Ophthalmology and Visual Sciences - UNIFESP program site, showing national and international postgraduates distribution.

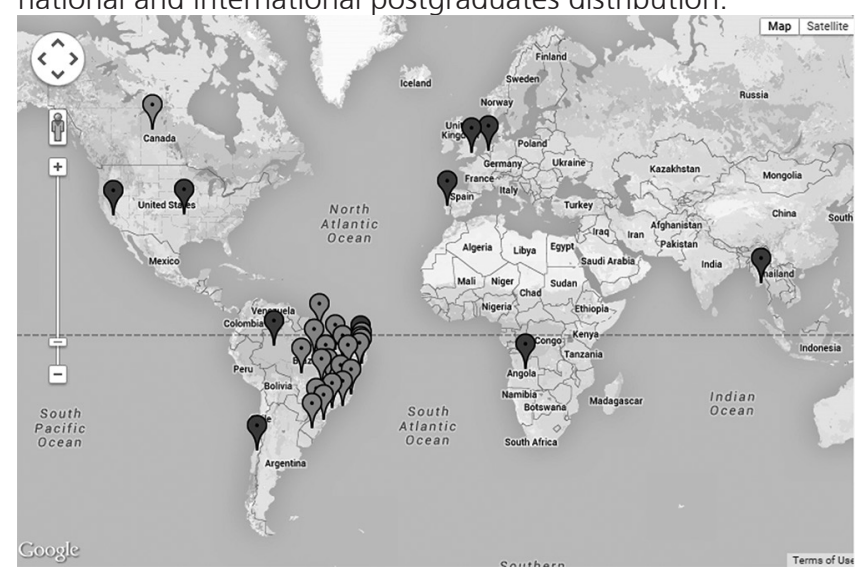

FIGURE 5 - Ophthalmology and Visual Sciences - UNIFESP program site, showing national and international postgraduates distribution.

\section{DISCUSSION}

When we try to understand the difficulties faced by postgraduate programs for alumni assessing we face the first, large and greatest obstacle: how to find them? One would have an option to register them in the USP Janus system. To do it, is necessary to make alumni invitation to participate answering a questionnaire. Usually the answer appears only when there is student interest on it. So, the questionnaire or form to be filled must be accessible, comprehensive, concise and very practical to attract postgraduates. There will still be other options, such as access to the authorship and co-authorships on Medline, social networks and also the Lattes curriculum, which requires a lot of hard work. Who should do it? The secretaries of the programs? The secretariat of the institution? These are difficult issues solution, as many programs do not have personnel even to the basic needs.

It was clear by the results that we do not have full conditions, until now, to know where our national postgraduates are and, even harder, international ones.

Our experience shows that the programs, mostly, do not even know about their students returning from sandwich doctorate or post-doctorate abroad. The need of the application for grant involves normally only the guidance counselor and the student; often, the program coordinator only sign the request and, frequently, not registering it in the program, and even less at the institution. In returning, the student makes directly contact with the scholarship agency (CAPES, CNPq and FAPESP), and so it is difficult to recover directions of students who finished the courses.

Therefore, it is clear that we urgently need a proposal involving data collection and evaluation mechanisms of the students who have gone to such important experience. It can be made at the institutional level. For example through annual meetings presenting all positive and negative aspects of lived experience. On the other hand, it could also be done at program level, demanding early filling protocol form and, at the end, full report of the guidance counselor and student activities.

A very interesting example, registered on the site of the Institute for Advanced Studies at USP - Polo Ribeirão Preto, is an annual meeting entitled "When the academy meets culture - young Brazilian researchers abroad", with the participation of students from post doctorate and sandwich doctorate in international environment, including international guests. Reported goals are: 1) to present and discuss projects and scientific protocols developed by postgraduate students and post doctorate in internships abroad; 2) to emphasize the cultural differences, the meaning of these experiences and their impact on the future teaching/researcher professional exercise; 3) to contribute and encourage other young researchers who are planning to stage outside Brazil and realize their plans abroad.

We believe that charging is very important; it is a way to evaluate and know the real contribution to the formation of one researchers elite in education. Knowing the results, it's possible to lead strategies in decision making that can enables directions correction to improve quality.

\section{CONCLUSION}

It is urgent: 1) to create project and funding evaluation mechanisms for approved researches paid by different sources; 2) to stimulate more efficient controls in relation to teachers and their students who participate in these projects; and 3) to stimulate the interaction of teachers and students with the institution and the program.

\section{RESUMO}

Objetivo: Verificar a existência de referências aos egressos internacionais nos sites dos programas de pós-graduação de todos os cursos de pós-graduação da Faculdade de Medicina de Ribeirão Preto - FMRP. Métodos: Verificar com mais atenção aos cursos notas 5 , 6 e 7, e também a mesma busca nos sites dos cursos com notas 5, 6 e 7 da Medicina III da CAPES. Resultados: Dos 22 programas da FMRP apenas três tinham no site alguma informação sobre o destino dos egressos, foram eles: Clínica Cirúrgica, Genética e Imunologia Básica e Aplicada. Dos programas da área de Medicina III, notas 5, 6 e 7 apenas os programas de Oftalmologia e Ciências Visuais e Cirurgia Translacional, ambos da UNIFESP, apresentavam informações sobre o destino dos seus egressos. Conclusão: É urgente criar mecanismos de avaliação para os projetos de incentivo e fomento à pesquisa dos diferentes órgãos; estimular controles mais eficientes e atualizados em relação aos docentes e seus respectivos discentes que participam desses projetos; e estimular a interação dos docentes e discentes com a instituição e o programa.

Descritores - Avaliação de egressos. Política de monitoramento. Egressos internacionais.

\section{REFERENCES}

1. Clínica cirúrgica - FMRP-USP - http://prpg.usp.br/pgcirurgia

2. Imunologia Básica - FMRP-USP - http://iba.fmrp.usp.br/

3. Genética - FMRP-USP - http://rge.fmrp.usp.br/pgnovo/

4. Oftalmologia e Ciências Visuais - UNIFESP - http://dgi.unifesp.br/sites/ comunicacao/pdf/entreteses/CatalogoPPG_jun2014.pdf

5. Cirurgia Translacional - UNIFESP- http://dgi.unifesp.br/sites/comunicacao/pdf/entreteses/CatalogoPPG_jun2014.pdf
Received on: 19/02/2015

Accepted for publication: 12/09/2015

Conflict of interest: none

Source of funding:

Address for correspondence:

Wilma Terezinha Anselmo Lima

wtalima@fmrp.usp.br 